Biogeosciences Discuss., https://doi.org/10.5194/bg-2018-126

Manuscript under review for journal Biogeosciences

Discussion started: 28 March 2018

(c) Author(s) 2018. CC BY 4.0 License.

\title{
Impacts of Nitrogen Addition on Nitrous Oxide Emission: Model- Data Comparison
}

\author{
Yujin Zhang ${ }^{1}$, Minna Ma ${ }^{2}$, Huajun Fang ${ }^{3}$, Dahe Qin ${ }^{1}$, Shulan Cheng ${ }^{4}$, and Wenping Yuan ${ }^{1 *}$ \\ ${ }^{1}$ State Key Laboratory of Cryospheric Sciences, Northwest Institute of Eco-Environment and Resources, Chinese Academy \\ 5 of Sciences, Lanzhou, Gansu 730000, China \\ ${ }^{2}$ School of Atmospheric Sciences, Sun Yat-Sen University, Zhuhai, Guangdong, 519082, China \\ ${ }^{3}$ Key Laboratory of Ecosystem Network Observation and Modeling, Institute of Geographical Sciences and Natural \\ Resources Research, Chinese Academy of Sciences, Beijing, China \\ ${ }^{4}$ College of Resources and Environment, University of Chinese Academy of Sciences, Beijing 100049, China
}

10 Corresponding author: Wenping Yuan (wyuan@lzb.ac.cn)

\begin{abstract}
.
The contributions of long-lived nitrous oxide $\left(\mathrm{N}_{2} \mathrm{O}\right)$ to the global climate and environment have received increasing attention. Especially, atmospheric nitrogen $(\mathrm{N})$ deposition has substantially increased in recent decades due to extensive use of fossil fuels in industry, which strongly stimulates the $\mathrm{N}_{2} \mathrm{O}$ emissions of the terrestrial ecosystem. Several models have

15 been developed to simulate $\mathrm{N}_{2} \mathrm{O}$ emission, but there are still large differences in their $\mathrm{N}_{2} \mathrm{O}$ emission simulations and responses to atmospheric deposition over global or regional scales. Using observations from $\mathrm{N}$ addition experiments in a subtropical forest, this study compared six widely-used $\mathrm{N}_{2} \mathrm{O}$ models (i.e. DayCENT, DLEM, DNDC, DyN, NOE, and NGAS) to investigate their performances for reproducing $\mathrm{N}_{2} \mathrm{O}$ emission, and especially the impacts of two types of $\mathrm{N}$ additions (i.e. ammonium and nitrate: $\mathrm{NH}_{4}{ }^{+}$and $\mathrm{NO}_{3}{ }^{-}$, respectively) and two levels (low and high) on $\mathrm{N}_{2} \mathrm{O}$ emission. In general, the six models reproduced the seasonal variations of $\mathrm{N}_{2} \mathrm{O}$ emission, but failed to reproduce relatively larger $\mathrm{N}_{2} \mathrm{O}$ emissions due to $\mathrm{NH}_{4}{ }^{+}$compared to $\mathrm{NO}_{3}{ }^{-}$additions. Few models indicated larger $\mathrm{N}_{2} \mathrm{O}$ emission under high $\mathrm{N}$ addition levels for both $\mathrm{NH}_{4}{ }^{+}$ and $\mathrm{NO}_{3}{ }^{-}$. Moreover, there were substantial model differences for simulating the ratios of $\mathrm{N}_{2} \mathrm{O}$ emission from nitrification and denitrification processes due to disagreements in model structures and algorithms. This analysis highlights the need to improve representation of $\mathrm{N}_{2} \mathrm{O}$ production and diffusion, and the control of soil water-filled pore space on these processes in order to simulate the impacts of $\mathrm{N}$ deposition on $\mathrm{N}_{2} \mathrm{O}$ emission.
\end{abstract}

Keywords: Nitrous oxide; Model; Nitrogen deposition; Forest; Model-data comparison 
Biogeosciences Discuss., https://doi.org/10.5194/bg-2018-126

Manuscript under review for journal Biogeosciences

Discussion started: 28 March 2018

(c) Author(s) 2018. CC BY 4.0 License.

Discussions

(c) (1)

\section{Introduction}

Nitrous oxide $\left(\mathrm{N}_{2} \mathrm{O}\right)$ is one of the most important greenhouse gases, and contributes $6.24 \%$ to overall global radiative forcing as the third contributor after carbon dioxide and methane (Forster et al., 2007; WMO, 2011). $\mathrm{N}_{2} \mathrm{O}$ plays an important role in depleting stratospheric ozone, which decreases harmful ultra-violet radiation reaching the earth. A doubling of the atmospheric $\mathrm{N}_{2} \mathrm{O}$ concentration could decrease the ozone layer by $10 \%$ (Crutzen and Ehhalt, 1977; Ravishankara et al., 2009). Since the industrial revolution, the atmospheric $\mathrm{N}_{2} \mathrm{O}$ concentration has increased nearly $21 \%$ from about 270 ppbv during the pre-industrial era to $325.9 \mathrm{ppbv}$ in 2013, with an average increase rate of about $0.82 \mathrm{ppbv} \mathrm{yr}^{-1} \mathrm{during}$ the last decade (WMO, 2014). Terrestrial ecosystems can act as either sources or sinks for atmospheric $\mathrm{N}_{2} \mathrm{O}$, depending on time and location (Potter et al., 1997; Ridgwell et al., 1999; Chapuis-Lardy et al., 2007; Xu et al., 2008). Globally, natural sources from terrestrial ecosystems contribute more than $50 \%$ to the $\mathrm{N}_{2} \mathrm{O}$ releases to the atmosphere (Denman et al., 2007). Quantifying $\mathrm{N}_{2} \mathrm{O}$ fluxes in global terrestrial ecosystems, therefore, is an urgent task for predicting future climate change (Sheldon and Barnhart, 2009).

Several process-based $\mathrm{N}$ cycle models have been developed and widely used for quantifying the spatial-temporal variations in $\mathrm{N}_{2} \mathrm{O}$ flux (Li et al., 1992; Engel and Prentice, 1993; Grant et al., 1993; Potter et al., 1996; Xu and Prentice,

45 2008; Zhuang et al., 2012). In general, these models usually integrate key biogeochemical processes, including nutrient mineralization, immobilization, nitrification, and denitrification. However, there exist substantial model disagreements in the estimated magnitude and spatial distribution of $\mathrm{N}_{2} \mathrm{O}$ at regional and global scales (Figure 1). For example, $\mathrm{Xu}$ and Prentice (2008) used the DyN model to estimate global terrestrial ecosystem $\mathrm{N}_{2} \mathrm{O}$ emission at $13.31 \mathrm{Tg} \mathrm{N} \mathrm{yr}^{-1}$, which is 3.94 times the estimate of 3.37 $\mathrm{Tg} \mathrm{N} \mathrm{yr}^{-1}$ arrived at by Zhuang et al. (2012) (Figure 1).

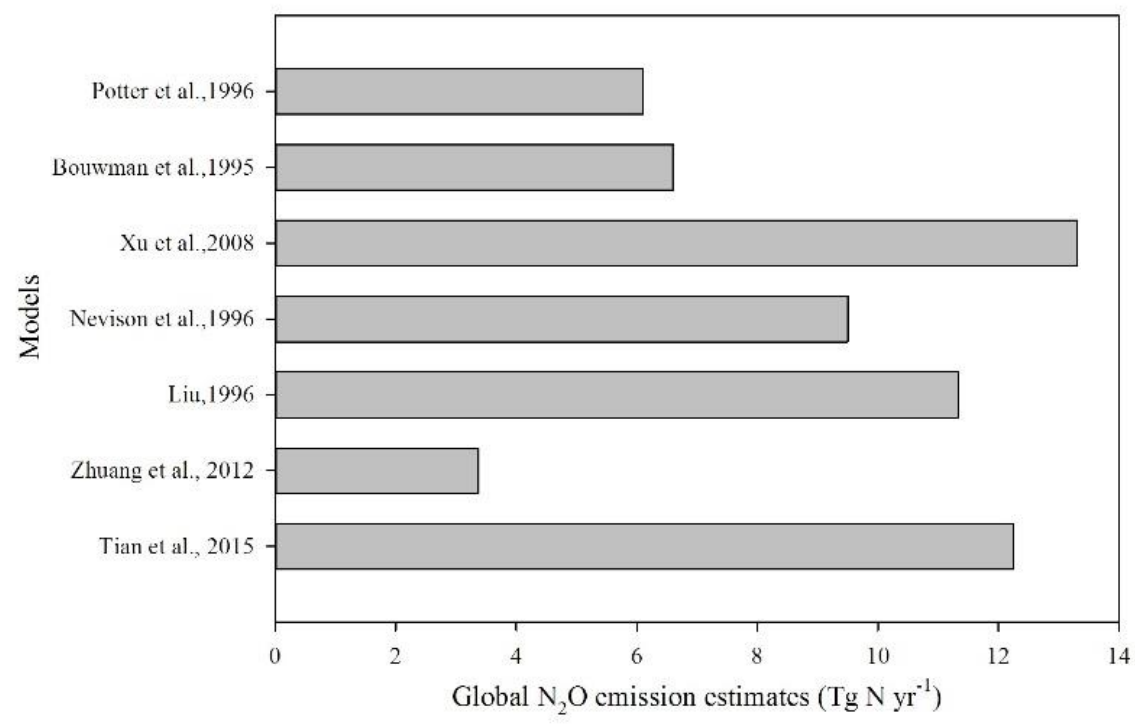

Figure 1. Comparison of global estimates of $\mathrm{N}_{2} \mathrm{O}$ emission from the terrestrial ecosystem. 
Biogeosciences Discuss., https://doi.org/10.5194/bg-2018-126

Manuscript under review for journal Biogeosciences

Discussion started: 28 March 2018

(c) Author(s) 2018. CC BY 4.0 License.

Each model is a combination of equations describing environmental regulations of $\mathrm{N}_{2} \mathrm{O}$ emission. Individual model validations, however, are not sufficient to identify the sources of the wide range of model differences. A rigorous comparison must be conducted in a standardized framework with consistent validation datasets and driving variables. To generate more robust estimates of $\mathrm{N}_{2} \mathrm{O}$ flux dynamics, it is necessary to compare estimates from a variety of $\mathrm{N}_{2} \mathrm{O}$ models and compare them against consistent and extensive measurements that are available.

Atmospheric nitrogen $(\mathrm{N})$ deposition, which is closely related to $\mathrm{N}_{2} \mathrm{O}$ emission, has shown a strong increasing trend in recent decades due to the extensive use of fossil fuels in industry and transportation and the heavy application of fertilizers in agriculture (Galloway et al., 2004). It is estimated that global atmospheric $\mathrm{N}$ deposition has increased from $1 \mathrm{Tg} \mathrm{N}$ in the

601860 s to $25-40 \mathrm{Tg} \mathrm{N}$ in the 2000 s, and is projected to continuously increase to $210 \mathrm{Tg} \mathrm{N}$ by the year 2050 (Neff et al., 2002; Lamarque et al., 2005; Galloway et al., 2008; Lu et al., 2016). The forest ecosystem in eastern China was recognized as the region receiving the highest atmospheric $\mathrm{N}$ deposition in southeast China (Liu et al., 2013). The $\mathrm{N}$ deposition input into terrestrial ecosystems alters plant physiology and the soil microbial community (Litten et al., 2007; Treseder, 2008), thereby changing the soil biogenic $\mathrm{N}_{2} \mathrm{O}$ flux (Butterbach-Bahl, 1997; Allen et al., 2004; Bange, 2006; Chen et al., 2015). Based on a meta-analysis of $\mathrm{N}$ addition experimental data worldwide, Liu and Greaver (2009) concluded that $\mathrm{N}$ addition could increase $\mathrm{N}_{2} \mathrm{O}$ emission by up to $216 \%$. In general, chronic $\mathrm{N}$ deposition will increase ammonium $\left(\mathrm{NH}_{4}{ }^{+}\right)$and nitrate $\left(\mathrm{NO}_{3}{ }^{-}\right)$ availability in terrestrial ecosystems, thereby affecting $\mathrm{N}_{2} \mathrm{O}$ flux through changing the activity and composition of the microbial community (Smith et al., 2003; Bowden et al., 2004; Monteny et al., 2006). However, to our knowledge, few studies have evaluated model performance in simulating the impacts of $\mathrm{N}$ deposition on $\mathrm{N}_{2} \mathrm{O}$ emission.

In this study, six widely-used $\mathrm{N}_{2} \mathrm{O}$ models, i.e. DayCENT (the daily version of the CENTURY ecosystem model; Parton et al., 1996, 2001; Del Grosso et al., 2001), DNDC (the Denitrification-Decomposition model; Li et al., 2000), DLEM (Dynamic Land Ecosystem Model; Tian et al., 2010), DyN (the global Dynamic Nitrogen model; Xu and Prentice, 2008), NOE (the algorithm of Nitrous Oxide Emission; Henault et al., 2005), and NGAS (a hybrid of a process-oriented model and a nutrient cycling model; Parton et al., 1996), were chosen for examination of their performance under different

75 levels of $\mathrm{N}$ deposition in a subtropical forest in southeast China. The study aims to (i) examine performance of the models in a forest ecosystem, particularly for seasonal variations of $\mathrm{N}_{2} \mathrm{O}$ emission, (ii) investigate the ability of these models under different levels of $\mathrm{N}$ deposition as well as two $\mathrm{N}$ types, and (iii) identify the key issues in the application of these models and future model development so as to improve their simulation of $\mathrm{N}_{2} \mathrm{O}$ emissions.

\section{Materials and Methods}

\subsection{Study Site}

This model-data comparison is based on field experiments conducted at a subtropical evergreen forest station, the

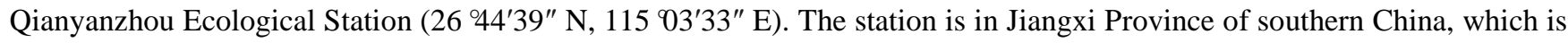
one of the important regions subject to atmospheric $\mathrm{N}$ deposition. The study plots were located in the slash pine plantation 
Biogeosciences Discuss., https://doi.org/10.5194/bg-2018-126

Manuscript under review for journal Biogeosciences

Discussion started: 28 March 2018

(c) Author(s) 2018. CC BY 4.0 License.

established in 1958. Average tree height was about $15 \mathrm{~m}$, with diameter at breast height of $16.1 \mathrm{~cm}$, stand basal area of $35 \mathrm{~m}^{2}$ $\mathrm{ha}^{-1}$, and leaf area index of 4.5. Dominant understory and midstory species are Woodwardia japonica (L.f.) Sm., Dicranopteris dichotoma (Thunb.) Bernh., Loropetalum chinense (R.Br.) Olv., and Quercus fabrei Hance. The typical soil is weathered from red sandstone and mud stone. Soil texture is divided into 2.0-0.05 mm (17\%), 0.05-0.002 mm (68\%), and $<0.002 \mathrm{~mm}(15 \%)$. Soil bulk density, organic carbon, total $\mathrm{N}$ content, and $\mathrm{pH}$ of the surface part $\left(0-40 \mathrm{~cm}^{2} \mathrm{were} 1.57 \mathrm{~g} \mathrm{~cm}^{-}\right.$ $3,7.2 \mathrm{~g} \mathrm{~kg}^{-1}, 0.55 \mathrm{~g} \mathrm{~kg}^{-1}$, and 4.6, respectively. The study site has a humid monsoon climate with a mean air temperature of

$9017.9^{\circ} \mathrm{C}$ and precipitation of $1469 \mathrm{~mm}$ per year. A large portion of the precipitation occurs in spring and early summer, but it is relatively dry in late summer and autumn with high air temperatures and low precipitation.

\subsection{Field Experiments}

The field experiments were conducted during April-December 2012. According to previously reported levels of atmospheric $\mathrm{N}$ deposition at the study area (Wang et al., 2011), two levels (low and high $\mathrm{N}$ of 0 and $120 \mathrm{~kg} \mathrm{~N}^{-1} \mathrm{yr}^{-1}$, respectively) of two different $\mathrm{N}$ fertilizers $\left(\mathrm{NH}_{4} \mathrm{Cl}\right.$ and $\left.\mathrm{NaNO}_{3}\right)$ were applied to mimic two future scenarios of $\mathrm{N}$ deposition. At the same time, a control experiment was carried out for comparison. Each level of $\mathrm{N}$ treatment was conducted in a plot of $20 \mathrm{~m} \times 20 \mathrm{~m}$ with a space of $10 \mathrm{~m}$ between any two plots. The $\mathrm{N}$ fertilizer solutions were sprayed on the plots once a month in 12 equal applications, and the control plots received only equivalent deionized water.

Flux data of $\mathrm{N}_{2} \mathrm{O}$ were determined using a static opaque chamber and gas chromatography method (Fang et al., 2014), which were installed near an eddy covariance tower in the ecological station. Daily fluxes were collected from the measurements approximately every two weeks. The soil fluxes were calculated based on the rate of changes in their concentration within the chamber, estimated as the slope of the linear regression between concentration and time (Wang et al., 2011). Soil temperature at 5 and $10 \mathrm{~cm}$ depths were monitored at each chamber site, using portable temperature probes (JM624 digital thermometer, Living-Jinming Ltd., Tianjin, China). At the same time, soil samples were collected nearby the static chambers from a depth of $0-20 \mathrm{~cm}$ using an auger $(2.5 \mathrm{~cm}$ in diameter $)$. Volumetric soil moisture $\left(\mathrm{m}^{3} \mathrm{~m}^{-3}\right) \mathrm{was}^{-}$ measured using a moisture probe meter (TDR100, Spectrum Technologies Inc., PlainField, IL, USA). Soil pH was also measured using the potentiometry method. Soil water-filled pore space (WFPS) was calculated using the methods reported by Fang et al. (2014).

\section{3. $\mathrm{N}_{2} \mathrm{O}$ Models}

Six $\mathrm{N}_{2} \mathrm{O}$ models were selected in this model-data comparison: DayCENT (Parton et al., 1996, 2001; Del Grosso et al., 2001), DNDC (Li et al., 2000), DLEM (Tian et al., 2010), DyN (Xu and Prentice, 2008), NOE (Henault et al., 2005), and NGAS (Parton et al., 1996). All six investigated $\mathrm{N}_{2} \mathrm{O}$ models are based on two major microbial processes: nitrification and denitrification, which are separately simulated from these two processes using the following equation:

$$
F_{N_{2} O}=F_{n t}+F_{d n}
$$


Biogeosciences Discuss., https://doi.org/10.5194/bg-2018-126

Manuscript under review for journal Biogeosciences

Discussion started: 28 March 2018

(c) Author(s) 2018. CC BY 4.0 License.

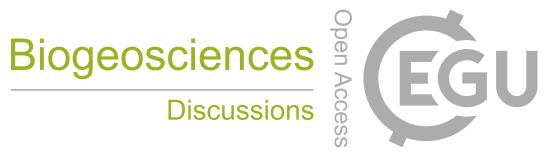

(c) (i)

115 where $F_{\mathrm{N}_{2} \mathrm{O}}$ is the $\mathrm{N}_{2} \mathrm{O}$ emission from soil to air $\left(\mathrm{g} \mathrm{N} \mathrm{m}^{-2}\right.$ day $\left.{ }^{-1}\right)$, and $F_{n t}$ and $F_{d n}$ are $\mathrm{N}_{2} \mathrm{O}$ emissions from nitrification and denitrification processes, respectively. Detailed model algorithms can be found from the Supplemental Online Materials.

\subsection{Simulation Protocol and Parameter Inversion}

The field observations of soil temperature, soil moisture, $\mathrm{pH}$, soil respiration, dissolved organic carbon, soil $\mathrm{NH}_{4}^{+}$ content, and soil $\mathrm{NO}_{3}{ }^{-}$content were used to drive the six models. As one of the key drivers, WFPS was derived using the following equation (Fang et al., 2014):

$W F P S=V W C /(1-B D / 2.65)$

where $V W C$ is soil volumetric moisture content $(\%), B D$ is soil bulk density $\left(\mathrm{g} \mathrm{cm}^{-3}\right)$, and 2.65 is soil particle density $\left(\mathrm{g} \mathrm{cm}^{-}\right.$ $\left.{ }^{3}\right)$.

The nonlinear regression procedure (Proc NLIN) in the Statistical Analysis System (SAS, SAS Institute Inc., Cary,

$125 \mathrm{NC}$, USA) was applied to optimize the model parameters using observed $\mathrm{N}_{2} \mathrm{O}$ emission for all five experiments. The calibrated parameter values were used to simulate $\mathrm{N}_{2} \mathrm{O}$ emissions (Table $\mathrm{S} 1$ ).

Three metrics were used to evaluate the performance of these models:

(i) The coefficient of determination between observation and simulation $\left(\mathrm{R}^{2}\right)$.

(ii) Absolute predictive error (PE), quantifying the difference between simulated and observed values.

130

(iii) Relative predictive error (RPE), computed as:

$R P E=(\bar{S}-\bar{O}) / \bar{O} \times 100$

where $\bar{S}$ and $\bar{O}$ are mean simulated and mean observed values, respectively.

\section{Results}

All six models generally reproduced the seasonal variations of measured $\mathrm{N}_{2} \mathrm{O}$ fluxes for the control and four $\mathrm{N}$

135 addition experiments. The measurements showed the largest $\mathrm{N}_{2} \mathrm{O}$ emissions during April-July, and the lowest in winter (Figure 2). The simulated emissions showed some differences in estimates for various models. Although the simulated $\mathrm{N}_{2} \mathrm{O}$ emissions from different models decreased from spring and summer to autumn and winter, indicating the seasonal pattern of emissions (Figure 1), there were some abrupt changes in model estimates. Most models captured the peak and trough of $\mathrm{N}_{2} \mathrm{O}$ emission. Collectively, the six models explained $1 \%-16 \%$ of the variations in $\mathrm{N}_{2} \mathrm{O}$ fluxes across all experiment plots (Table $1401)$. 
Biogeosciences Discuss., https://doi.org/10.5194/bg-2018-126

Manuscript under review for journal Biogeosciences

Discussion started: 28 March 2018

(c) Author(s) 2018. CC BY 4.0 License.

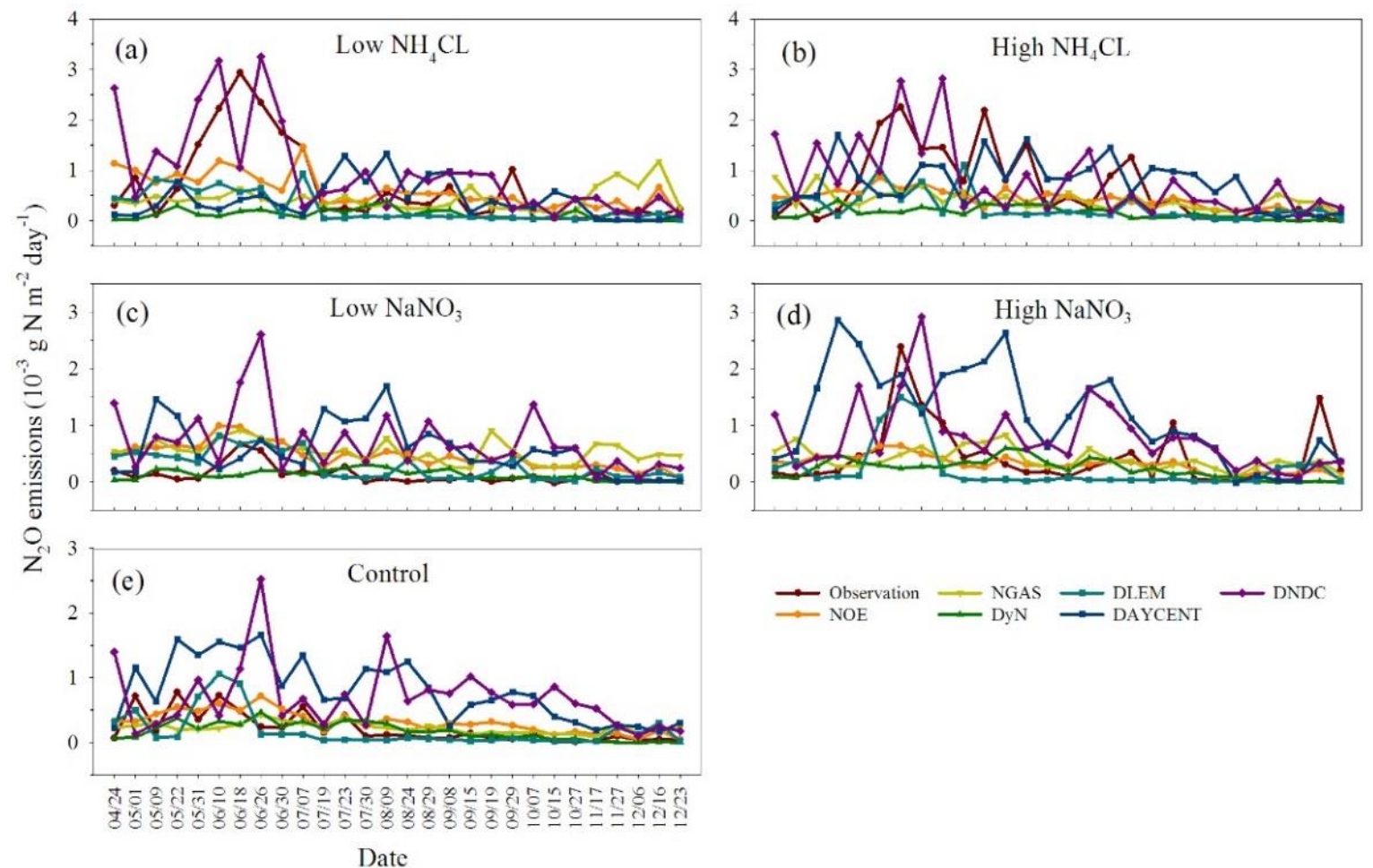

Figure 2. Comparisons of $\mathrm{N}_{2} \mathrm{O}$ emission simulations and observations for five experiment treatments.

Most models did not fully indicate the stimulations of $\mathrm{N}$ additions to $\mathrm{N}_{2} \mathrm{O}$ emission that were observed in field experiments. According to the observed $\mathrm{N}_{2} \mathrm{O}$ fluxes, $\mathrm{NO}_{3}{ }^{-}$and $\mathrm{NH}_{4}{ }^{+}$additions increased $\mathrm{N}_{2} \mathrm{O}$ emission for four addition experiments, and high $\mathrm{NO}_{3}^{-}$and $\mathrm{NH}_{4}{ }^{+}$additions led to higher $\mathrm{N}_{2} \mathrm{O}$ emission compared to low additions (Figure 3). Furthermore, larger increases of $\mathrm{N}_{2} \mathrm{O}$ emission occurred for $\mathrm{NH}_{4}{ }^{+}$- compared to $\mathrm{NO}_{3}{ }^{-}$-addition experiments (Figure 3). However, NGAS, DyN, DayCENT, and DNDC models simulated larger $\mathrm{NO}_{2}$ fluxes for low compared to high $\mathrm{NH}_{4}{ }^{+}-$ addition treatments (Figure 3). NOE and NGAS did not correctly indicate the differences of $\mathrm{N}_{2} \mathrm{O}$ fluxes between high and low $\mathrm{NO}_{3}{ }^{-}$treatments. In addition, the experiments also indicated higher simulations of $\mathrm{N}_{2} \mathrm{O}$ emission for $\mathrm{NH}_{4}^{+}$compared with $\mathrm{NO}_{3}{ }^{-}$additions. However, only $\mathrm{NOE}$ and DLEM models reproduced larger impacts of $\mathrm{NH}_{4}{ }^{+}$on $\mathrm{N}_{2} \mathrm{O}$ emissions compared with low $\mathrm{NH}_{4}{ }^{+}$level.

Table 1. Predictions of the six $\mathrm{N}_{2} \mathrm{O}$ models for four $\mathrm{N}$ addition treatments

\begin{tabular}{|c|c|c|c|c|c|c|}
\hline & Model/N level & Low $\mathrm{NH}_{4} \mathrm{Cl}$ & High $\mathrm{NH}_{4} \mathrm{Cl}$ & $\mathrm{Low}_{\mathrm{NaNO}}$ & $\mathrm{High}_{\mathrm{NaNO}_{3}}$ & Control \\
\hline Obs & Mean $^{\#}$ & $0.69^{\mathrm{b}}$ & $1.14^{\mathrm{a}}$ & $0.29^{c}$ & $0.78^{\mathrm{ab}}$ & $0.18^{\mathrm{c}}$ \\
\hline \multirow{4}{*}{ NOE } & Mean & $0.62^{\mathrm{ab}}$ & $0.62^{\mathrm{b}}$ & $0.53^{\mathrm{b}}$ & $0.48^{\mathrm{b}}$ & $0.47^{\mathrm{a}}$ \\
\hline & $\mathrm{R}^{2}$ & $0.55^{*}$ & $0.35^{*}$ & $0.61^{*}$ & $0.40^{*}$ & $0.33^{*}$ \\
\hline & $\mathrm{PE}$ & -0.07 & -0.51 & 0.24 & -0.30 & 0.29 \\
\hline & RPE (\%) & -11.16 & -44.92 & 84.45 & -38.43 & 163.51 \\
\hline
\end{tabular}


Biogeosciences Discuss., https://doi.org/10.5194/bg-2018-126

Manuscript under review for journal Biogeosciences

Discussion started: 28 March 2018

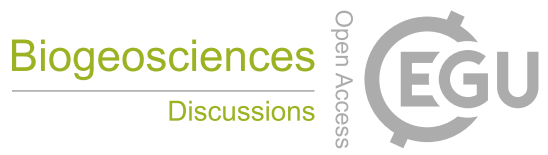

(c) Author(s) 2018. CC BY 4.0 License.

(c) (i)

\begin{tabular}{|c|c|c|c|c|c|c|}
\hline \multirow{4}{*}{ NGAS } & Mean & $0.55^{\mathrm{b}}$ & $0.29^{\mathrm{d}}$ & $0.49^{\mathrm{b}}$ & $0.35^{\mathrm{d}}$ & $0.22^{\mathrm{bc}}$ \\
\hline & $\mathrm{R}^{2}$ & 0.11 & $0.27^{*}$ & $0.50^{*}$ & 0.01 & $0.14^{*}$ \\
\hline & $\mathrm{PE}$ & -0.16 & -0.85 & 0.19 & -0.42 & 0.042 \\
\hline & RPE (\%) & -22.33 & -74.52 & 69.47 & -54.73 & 24.33 \\
\hline \multirow{4}{*}{ DyN } & Mean & $0.49^{\mathrm{b}}$ & $0.41^{\mathrm{c}}$ & $0.48^{\mathrm{bc}}$ & $0.58^{\mathrm{b}}$ & $0.43^{\mathrm{ab}}$ \\
\hline & $\mathrm{R}^{2}$ & $0.28^{*}$ & $0.23^{*}$ & $0.14^{*}$ & $0.15^{*}$ & $0.21^{*}$ \\
\hline & PE & -0.21 & -0.73 & 0.19 & -0.20 & 0.28 \\
\hline & RPE (\%) & -29.65 & -64.92 & 67.11 & -26.02 & 139.70 \\
\hline \multirow{4}{*}{ DLEM } & Mean & $0.51^{\mathrm{b}}$ & $0.79^{\mathrm{ab}}$ & $0.42^{\mathrm{bc}}$ & $0.43^{\mathrm{b}}$ & $0.29^{\mathrm{b}}$ \\
\hline & $\mathrm{R}^{2}$ & $0.38^{*}$ & $0.24^{*}$ & $0.58^{*}$ & $0.79^{*}$ & $0.57^{*}$ \\
\hline & PE & -0.19 & -0.35 & 0.14 & -0.39 & 0.11 \\
\hline & RPE (\%) & -27.46 & -30.87 & 47.86 & -44.51 & 64.15 \\
\hline \multirow{4}{*}{ DayCENT } & Mean & $0.61^{\mathrm{ab}}$ & $0.52^{\mathrm{a}}$ & $0.62^{\mathrm{ab}}$ & $0.98^{\mathrm{a}}$ & $0.51^{\mathrm{a}}$ \\
\hline & $\mathrm{R}^{2}$ & $0.13^{*}$ & $0.14^{*}$ & 0.01 & $0.23^{*}$ & $0.28^{*}$ \\
\hline & $\mathrm{PE}$ & -0.09 & -0.62 & 0.33 & 0.20 & 0.34 \\
\hline & RPE (\%) & -12.16 & -54.51 & 115.36 & 24.92 & 188.84 \\
\hline \multirow{4}{*}{ DNDC } & Mean & $0.92^{\mathrm{a}}$ & $0.78^{\mathrm{ab}}$ & $0.78^{\mathrm{a}}$ & $0.98^{\mathrm{a}}$ & $0.59^{\mathrm{a}}$ \\
\hline & $\mathrm{R}^{2}$ & $0.35^{*}$ & $0.13^{*}$ & $0.25^{*}$ & $0.31^{*}$ & 0.01 \\
\hline & $\mathrm{PE}$ & 0.22 & -0.36 & 0.49 & 0.19 & 0.41 \\
\hline & RPE (\%) & 30.85 & -31.94 & 172.51 & 24.80 & 234.71 \\
\hline
\end{tabular}

Note. Letters indicate significant differences among $\mathrm{N}_{2} \mathrm{O}$ values for the same levels of $\mathrm{N}$ addition from different model simulations or observation. $\mathrm{R}^{2}$ is the coefficient of determination between observation and simulation. PE is absolute

155 predictive error. RPE is relative predictive error. \# indicates the mean value of observed or simulated $\mathrm{N}_{2} \mathrm{O}$ emissions $\left(10^{-3} \mathrm{~g}\right.$ $\mathrm{N} \mathrm{m}^{-2}$ day $\left.^{-1}\right)$. * indicates the significance of $\mathrm{p}<0.05$. 
Biogeosciences Discuss., https://doi.org/10.5194/bg-2018-126

Manuscript under review for journal Biogeosciences

Discussion started: 28 March 2018

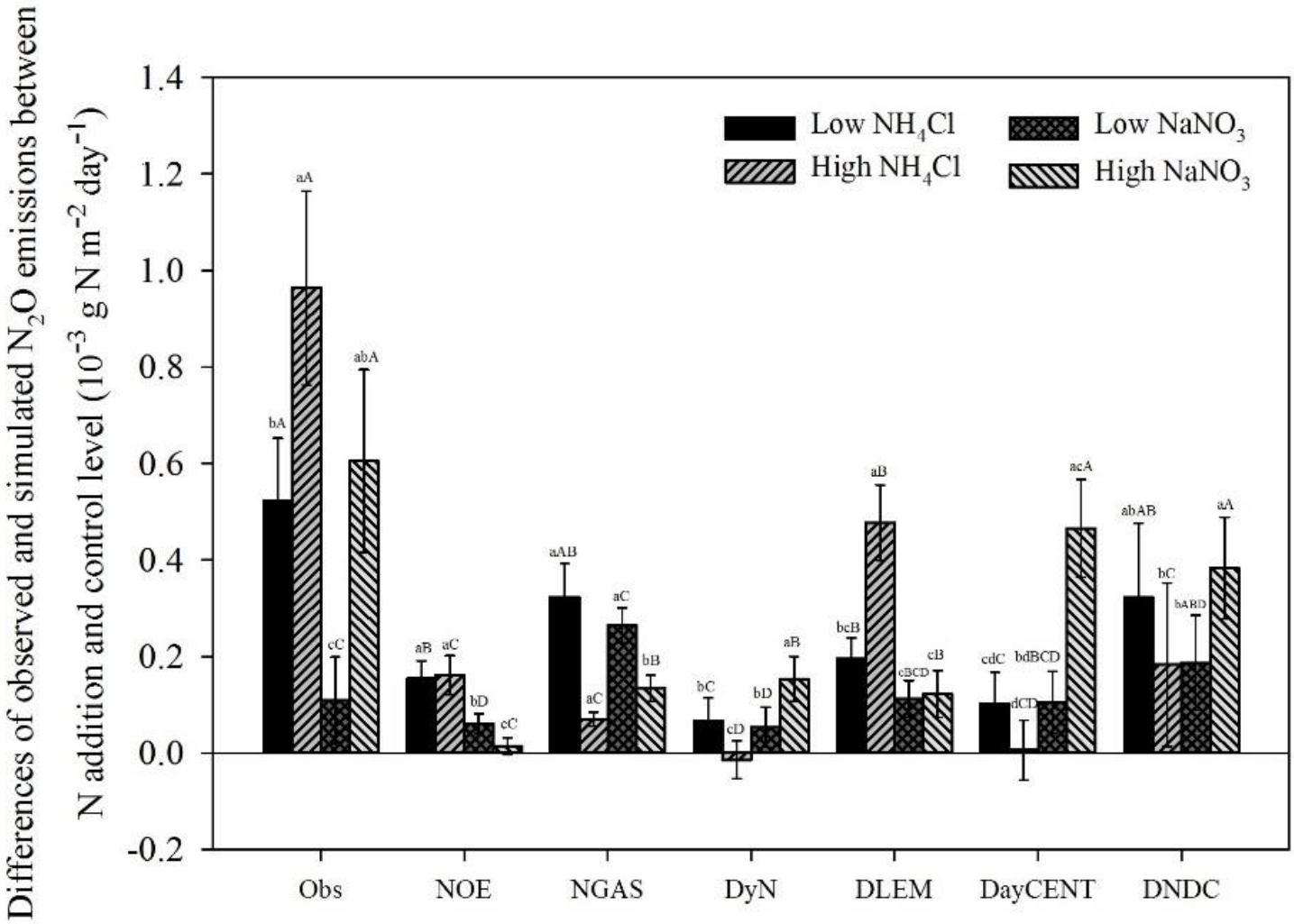

Figure 3. Comparisons of $\mathrm{N}_{2} \mathrm{O}$ emission differences between $\mathrm{N}$ addition and control treatments from observation and model simulations. Lower-case letters indicate significant differences among the values for different $\mathrm{N}$ addition level for an individual model or observation. Capital letters indicate the significant difference among the values for the same levels of $\mathrm{N}$ addition from different model simulations or observation.

Because $\mathrm{N}_{2} \mathrm{O}$ emissions are generally from two different microbial processes, i.e. nitrification and denitrification, the proportions of $\mathrm{N}_{2} \mathrm{O}$ emissions due to both processes were calculated to quantify their contributions to total emissions. All six models showed consistently negative correlations between the ratios of $\mathrm{N}_{2} \mathrm{O}$ emission from nitrification and WFPS (Figure 4a). The six models showed that nitrification contributed more than half of $\mathrm{N}_{2} \mathrm{O}$ emissions; however, there were large differences in the ratios of $\mathrm{N}_{2} \mathrm{O}$ fluxes generated by nitrification and denitrification among the models (Figure $4 \mathrm{~b}$ ). On average, the DayCENT model simulated the lowest ratio (about $55.4 \%$ ) of $\mathrm{N}_{2} \mathrm{O}$ emissions generated by nitrification, and the largest ratio (about $89.5 \%$ ) was for the DyN model (Figure $4 b$ ). 
Biogeosciences Discuss., https://doi.org/10.5194/bg-2018-126

Manuscript under review for journal Biogeosciences

Discussion started: 28 March 2018

(c) Author(s) 2018. CC BY 4.0 License.
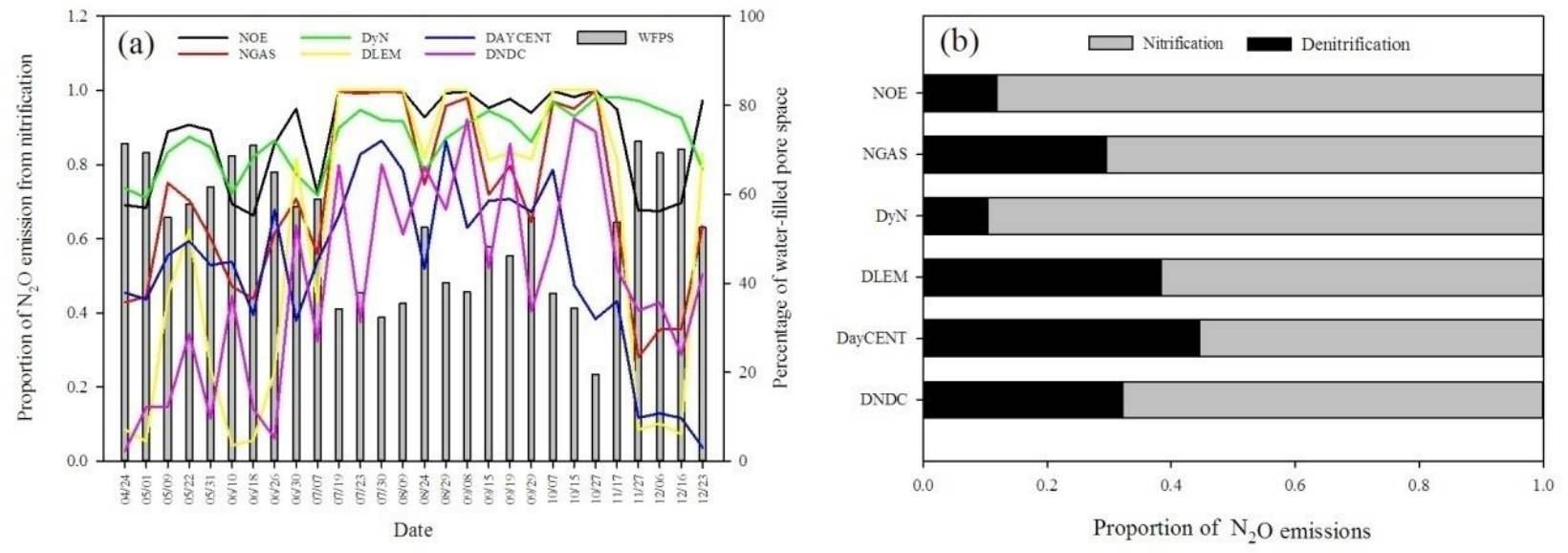

170 Figure 4. Proportions of $\mathrm{N}_{2} \mathrm{O}$ emissions for different models. (a) Seasonal proportion of $\mathrm{N}_{2} \mathrm{O}$ emission from nitrification and seasonal water-filled pore space (WFPS). (B) Averaged proportion of emissions from nitrification and denitrification.

\section{Discussion}

\subsection{Model Performance}

Compared with ecosystem carbon dioxide emissions, few studies have evaluated model performance for simulating

$175 \mathrm{~N}_{2} \mathrm{O}$ emissions due to the relative scarcity of $\mathrm{N}$ cycle measurements (Henault et al., 2012). Notably, $\mathrm{N}$ depositions from the atmosphere have been documented to increase with industry processes (Galloway et al., 2004), which are believed to have significant impacts on soil $\mathrm{N}_{2} \mathrm{O}$ emissions due to their impacts on microbial processes. Therefore, the sixth IPCC report, which will be conducted in the next five years, requires Earth System Models integrate N cycle (IPCC, 2017). Therefore, process-based $\mathrm{N}_{2} \mathrm{O}$ models have been widely developed and applied in recent years ( $\mathrm{Li}$ et al., 1992; Engel and Priesack, 1993; Parton et al., 1996; Potter et al., 1997; Del Grosso et al., 2001; Henault et al., 2005; Xu and Prentice, 2008; Tian et al., 2010). These models are now being used not only for the prediction of $\mathrm{N}_{2} \mathrm{O}$ emissions from different ecosystems, but estimation of $\mathrm{N}_{2} \mathrm{O}$ inventories on national, regional, and global scales, and for assessing climate change impacts and mitigation strategies (Del Grosso et al., 2006, 2009; EPA, 2006). However, it should be noted that these model predictions may not be reliable when applied to a new environment, and their performance should be first tested with different data streams from real world experiments.

Our comparison showed the general performance of six investigated models in reproducing seasonal variations and magnitudes of $\mathrm{N}_{2} \mathrm{O}$ emissions (Figure 2). This conclusion was supported by several recent model evaluations, which revealed unstable performance of $\mathrm{N}_{2} \mathrm{O}$ models (Senapati et al., 2016). For example, different studies with the DayCent model have found a range of correlations from weak to strong across different agroecosystems (Henault et al., 2012). Parton et al. (2001) found correlations between daily measured vs. simulated $\mathrm{N}_{2} \mathrm{O}$ emissions, with range $0-0.44$, from a variety of five 
Biogeosciences Discuss., https://doi.org/10.5194/bg-2018-126

Manuscript under review for journal Biogeosciences

Discussion started: 28 March 2018

(c) Author(s) 2018. CC BY 4.0 License.

different grassland sites in the USA. Other ecosystem models also face similar difficulties in simulation of daily $\mathrm{N}_{2} \mathrm{O}$ emissions, for example DNDC (Yeluripati et al., 2015) and CoupModel (He et al., 2016).

The comparison revealed the complexity in modeling the impacts of $\mathrm{N}$ addition on $\mathrm{N}_{2} \mathrm{O}$ emission. The field observations in the current study indicated larger $\mathrm{N}_{2} \mathrm{O}$ emissions for $\mathrm{NH}_{4}{ }^{+}$compared with $\mathrm{NO}_{3}{ }^{-}$additions at two addition levels (Figure 3). However, these impacts were not reproduced by all of the six models except for the DELM and NOE models. Previous study showed that the impacts of $\mathrm{NH}_{4}{ }^{+}$addition on $\mathrm{N}_{2} \mathrm{O}$ emissions are, to some extent, larger compared with $\mathrm{NO}_{3}{ }^{-}$addition (Wang et al., 2016). This is probably due to two primary reasons. One is that under favorable temperature and moisture, nitrification dominates $\mathrm{N}_{2} \mathrm{O}$ emission compared with denitrification if soil is acidic and rich in $\mathrm{NH}_{4}{ }^{+}$. The addition of $\mathrm{NH}_{4}{ }^{+}$can significantly increase the substrates for ammonia-oxidizers and the abundance of ammonia-oxidizing archaea, which give rise to increases in soil autotrophic nitrification rate (Gao et al., 2016a; 2016b). The other reason is that additions of $\mathrm{NH}_{4}{ }^{+}$fertilizers can have larger impacts on the acidification of soil compared with the additions of $\mathrm{NO}_{3}{ }^{-}$, which is closely related to the accumulation of $\mathrm{H}^{+}$in soil solution and the leaching of $\mathrm{NO}_{3}{ }^{-}$from soil (Tian and Niu, 2015). Soil acidification decreases availability of $\mathrm{NH}_{4}{ }^{+}$, which is favorable to the growth of soil nitrifiers, i.e. ammonia-oxidizing archaea, but unfavorable to soil denitrifiers (Isobe et al., 2012).

\subsection{Structure Differences among $\mathrm{N}_{2} \mathrm{O}$ Models}

The performance of these $\mathrm{N}_{2} \mathrm{O}$ models strongly depends on model algorithms, and also on the major pathways of $\mathrm{N}_{2} \mathrm{O}$ emissions and their responses to environmental conditions. This is because the processes of $\mathrm{N}_{2} \mathrm{O}$ emissions are extremely competitive and are controlled by many drivers, e.g. soil temperature, moisture, soil redox potential, and the availability of substrates for microbes (Schmidt et al., 2000). In the present study, the models did not adequately capture the environmental regulation of $\mathrm{N}_{2} \mathrm{O}$ emission. Nitrification and denitrification are two major processes of $\mathrm{N}_{2} \mathrm{O}$ production. Numerous experiments have shown that nitrification and denitrification can occur simultaneously because of the coexistence of aerobic and anaerobic zones in soils (Henault et al., 2012; Hu et al., 2015); however, the availability of soil oxygen-determined by soil water content and other soil properties - strongly regulates the proportion of nitrification and denitrification (Li et al., 1992). Numerous studies have investigated the relationship between soil moisture and the contributions of nitrification and

215 denitrification processes. In $\mathrm{N}$ fertilizer-amended soil, $\mathrm{N}_{2} \mathrm{O}$ emission has been found to be highly correlated with WFPS, with the highest emission at around $70 \%$ WFPS, which was attributed to a combination of nitrification (35\%-53\%) and denitrification (only $2 \%-9 \%$ ) (Huang et al., 2014). In sandy loam soils, when moisture status was sub-optimal for denitrification (50\% and $70 \%$ WFPS), nitrification was the significant contributor (around $29 \%$ ) to $\mathrm{N}_{2} \mathrm{O}$ emissions (Kool et al., 2011); however, in wetter soils $(-0.1 \mathrm{kPa})$ nitrification contributed less than $3 \%$ (Webster and Hopkins, 1996). Well et al. (2008) attributed $88 \%$ of total $\mathrm{N}_{2} \mathrm{O}$ emission to nitrification at $45 \%$ WFPS. This suggests that favorable conditions for $\mathrm{N}_{2} \mathrm{O}$ production from nitrification occur within the range of $30 \%-70 \%$, whereas denitrification dominates $\mathrm{N}_{2} \mathrm{O}$ production in wet soils with WFPS > $80 \%$ (Braker and Conrad, 2011; Huang et al., 2014). The values of WFPS in the current study were within the range of $30 \%-70 \%$, which was favorable to the occurrence of nitrification in all of these models. 
Biogeosciences Discuss., https://doi.org/10.5194/bg-2018-126

Manuscript under review for journal Biogeosciences

Discussion started: 28 March 2018

(c) Author(s) 2018. CC BY 4.0 License.

In general, all six $\mathrm{N}_{2} \mathrm{O}$ models use soil water content to control the balance of two processes. NOE uses a simplified scheme to separate the nitrification and denitrification processes. Nitrification only occurs if WFPS < $80 \%$, whereas denitrification only occurs if WFPS > $62 \%$; within the range of 62\%-80\%, the two processes may occur simultaneously (Henault et al., 2005). For DLEM, denitrification and nitrification are simulated as a one-step process. Due to the effect of soil moisture, denitrification only occurs when soil moisture exceeds field capacity (Tian et al., 2010). For DyN and DNDC, aerobic and anaerobic microsites are assumed to simultaneously exist in most soils. Nitrification occurs in aerobic microsites,

but denitrification is mainly in anaerobic microsites. The key factor affecting the ratio between aerobic and anaerobic microsites is soil redox potential, which controls the ratio between nitrification and denitrification ( $\mathrm{Li}$ et al., 1992; Xu and Prentice, 2008). For NGAS and DayCENT, no specific threshold is applied for the occurrences of the two processes and they are assumed to occur simultaneously (Parton et al., 1996, 2001; Del Grosso et al., 2001). Thus, the differences in the algorithms of the six models are believed to be the key reasons for the differences in the model estimates of $\mathrm{N}_{2} \mathrm{O}$ emission.

\section{Conclusions}

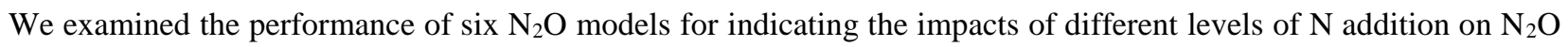
emission. Results indicated that the investigated models can represent the general seasonal variations of $\mathrm{N}_{2} \mathrm{O}$ emissions under both $\mathrm{N}$ addition and non-N addition levels. However, additions of $\mathrm{NH}_{4}{ }^{+}$rather than $\mathrm{NO}_{3}{ }^{-}$could have more significant effects on $\mathrm{N}_{2} \mathrm{O}$ emissions from soils, which were not represented by most of the models. In addition, most of the models failed to reproduce larger $\mathrm{N}_{2} \mathrm{O}$ emissions at high level of nitrate additions compared with ammonia additions. Moreover, the analysis suggested that the disagreements in model structure and algorithms resulted in substantial differences in $\mathrm{N}_{2} \mathrm{O}$ emission and mediating processes (i.e. nitrification and denitrification).

Competing interests. The authors declare that they have no conflict of interest.

Data availability. The data can be obtained upon request to the authors.

\section{Acknowledgments}

This study was supported by the National Key Basic Research Program of China (2016YFA0602701), the Major Programs of High-Resolution Earth Observation System (Grant No. 32-Y2-0A17-9001-15/17), the One Hundred Person Project of CAS, the National Youth Top-Notch Talent Support Program (2015-48), and the Youth Changjiang Scholars Programme of China (Q2016161). We thank many members of the filed crew who collected the field data for the study. We also thank the anonymous reviewers for their comments. 
Biogeosciences Discuss., https://doi.org/10.5194/bg-2018-126

Manuscript under review for journal Biogeosciences

Discussion started: 28 March 2018

(c) Author(s) 2018. CC BY 4.0 License.

\section{References}

Allen, A. S. and Schlesinger, W. H.: Nutrient limitations to soil microbial biomass and activity in loblolly pine forests, Soil Biol. Biochem., 36, 581-589, 2004.

Bange, H. W.: Nitrous oxide and methane in European coastal waters, Estuar. Coast. Shelf S., 70, 361-374, 2006.

Blagodatsky S. A. and Richter, O.: Microbial growth in soil and nitrogen turnover: a theoretical model considering the activity state of microorganisms, Soil Biol. Biochem., 3013, 1743-1755, 1998.

Bowden, R. D., Davidson, E., Savage, K., Arabia, C., and Steudler P.: Chronic Nitrogen additions reduce total soil respiration and microbial respiration in temperate forest soils at the Harvard Forest, Forest Ecol. Manag., 196, 43-56, 2004.

Braker, G. and Conrad, R.: Diversity, structure, and size of $\mathrm{N}_{2} \mathrm{O}$ producing microbial communities in soils-what matters for their functioning? Adv. Appl. Microbiol., 75, 33-70, 2011.

Breuer, L., Kiese, R. and Butterbach-Bahl, K.: Temperature and moisture effects on nitrification rates in tropical rain-forest soils, Soil Sci. Soc. Am. J., 66, 834-844, 2002.

Butterbach-Bahl, K., Gasche, R., Breuer, L., and Papen, H.: Fluxes of $\mathrm{NO}$ and $\mathrm{N}_{2} \mathrm{O}$ from temperate forest soils: Impact of forest type, $\mathrm{N}$ deposition and of liming on the $\mathrm{NO}$ and $\mathrm{N}_{2} \mathrm{O}$ emissions, Nutr. Cycl. Agroecosys., 48, 79-90, 1997.

Chapuis-Lardy, L., Wrage, L., Metay, A., Chotte, J. L., and Bernous, M.: Soils, a sink for $\mathrm{N}_{2} \mathrm{O}$ ? A review. Global Change Biol., 13, 1-17, doi: 10.1111/j.1365-2486.2006.01280.x, 2007.

Chen, D., Fu, X. Q., Wang, C., Liu, X. L., Li, H., Shen, J. L., Wang, Y., Li, Y., and Wu, J. S.: Nitrous Oxide Emissions from a Masson Pine Forest Soil in Subtropical Central China, Pedosphere, 252, 263-274, 2015.

Crutzen, P. J. and Ehhalt, D. H.: Effects of nitrogen fertilizers and combustion on the stratospheric ozone layer, Ambio, 6,112-117, 1977.

Del Grosso, S. J., Ojima, D. S., Parton, W. J., Stehfest, E., Heistemann, M., DeAngelo, B., and Rose, S.: Global scale DAYCENT model analysis of greenhouse gas emissions andmitigation strategies for cropped soils, Global and Planet. Change, 67, 44-50, 2009.

Del Grosso, S. J., Parton, W. J., Mosier, A. R., Ojima, D. S., Kulmala, A. E., and Phongpan, S.: General model for $\mathrm{N}_{2} \mathrm{O}$ and $\mathrm{N}_{2}$ gas emissions from soils due to denitrification, Global Biogeochem. Сy., 144, 1045-1060, 2000.

Del Grosso, S. J., Parton, W. J., Mosier, A. R., Walsh, M. K., Ojima, D. S., and Thornton, P. E.: DAYCENT national-scale simulations of nitrous oxide emissions from cropped soils in the United States, J. Environmen. Qual., 35, 1451-1460, 2006.

Del Grosso, S. J., Parton, W. J., Mosier, A. R., Hartman, M. D., Brenner, J., Ojima, D. S., and Schimel, D. S.: Simulated Interaction of Carbon Dynamics and Nitrogen Trace Gas Fluxes Using the DAYCENT Model, in: Modeling Carbon and Nitrogen Dynamics for Soil Management, Lewis Publisher, New York, 303-330, 2001.

Denman, K. L., Brasseur, G., Chidthaisong, A., Ciais, P., Cox, P. M., Dickinson, R. E., Hauglustaine D. A., Heinze, C., 
Biogeosciences Discuss., https://doi.org/10.5194/bg-2018-126

Manuscript under review for journal Biogeosciences

Discussion started: 28 March 2018

(c) Author(s) 2018. CC BY 4.0 License.

Holland, E. A., Jacob, D. J., Lohmann, U., Ramachandran, S., Silva Dias, P. L., Wofsy, S. C., and Zhang, X. Y.: Couplings between Changes in the Climate System and Biogeochemistry, in Climate Change 2007: The Physical Science Basis, Contribution of Working Group I to the Fourth Assessment Report of the Intergovernmental Panel on Climate Change, NY, USA: Cambridge University Press, Cambridge, United Kingdom and New York, 501-568, 2007.

Engel, T. H., and Priesack, E.: Expert-N, a building block system of nitrogen models as a resource for advice, research, water management and policy, in: Integrated Soil and Sediment Research: A Basis for Proper Protection, Kluwer Academic Publishers, Dordrecht, Netherland, 503-507, 1993.

EPA: Inventory of U.S. Greenhouse Gas Emissions and Sinks: 1990-2004, Washington, D. C., USA, 2006.

EPA: Integrated science assessment for oxides of nitrogen and sulfur-environmental criteria, United States Environmental Protection Agency, Washington, D. C., USA, 2008.

Fang, H. J., Cheng, S. L., Yu, G. R., Cooch, J., Wang, Y. S., Xu, M. J., Li, L. S., Dang, X. S., and Li, Y. N.: Low-level nitrogen deposition significantly inhibits methane uptake from an alpine meadow soil on the Qinghai-Tibetan Plateau, Geoderma, 213, 444-452, 2014.

Forster, P., Ramaswamy, V., Artaxo, P., Berntsen, T., Betts, R., Fahey, D. W., Haywood, J., Lean, J., Lowe, D. C., Myhr, G., Nganga, J., Prinn, R., Raga., G., Schulz, M., and Van Dorland, R.: Changes in atmospheric constituents and in radiative forcing, in: Climate Change 2007: The Physical Science Basis Contribution of Working Group I to the Fourth Assessment Report of the Intergovernmental Panel on Climate Change, Cambridge University Press, Cambridge, UK, 131-217, 2007.

Galloway, J. N., Dentender, F., Capone, D. G., Boyer, E. W., Howarth, R. W., Seizinger, S. P., and Vorosmarty, C. J.: Nitrogen cycles: past, present, and future, Biogeochemistry, 70, 153-226, 2004.

Galloway, J. N., Townsend, A.R., Erisman, J. W., Bekunda, M., Cai, Z. C., Freney, J. R., Martinelli, L. A., Seitzinger, S. P., and Sutton, M.: Transformation of the Nitrogen Cycle: Recent Trends, Questions, and Potential Solutions, Science, 320, $16,2008$.

Gao, W. L., Kou, L., Yang, H., Zhang, J. B., Muller, C., and Li, S. G.: Are nitrate production and retention process in subtropical acidic forest soil responsive to ammonium deposition? Soil Biol. Biochem., 100, 102-109, 2016a.

Gao, W. L., Kou, L., Zhang, J. B., Muller, C., Wang, H. M., Yang, H., and Li, S. G.: Enhanced deposition of nitrate alters microbial cycling of $\mathrm{N}$ in a subtropical forest soil, Biol. Fert. Soils, 52, 977-986, $2016 \mathrm{~b}$.

Garcia-Ruiz, R., Pattinson, S. N., and Whitton, B. A.: Kinetic parameters of denitrification in a river continuum, Appl. Environ. Microb., 64, 2533-2538, 1998.

315 Garrido, F., Henault, C., Gaillard, H., Perez, S., and Germon, J. C.: $\mathrm{N}_{2} \mathrm{O}$ and NO emissions by agricultural soils with low hydric potentials, Soil Biol. Biochem., 34, 559-575, 2002.

Grant, R. F., Nyborg, M., and Laidlaw, L. W.: Evolution of nitrous oxide from soil: I. model development, Soil Sci., 156, 259-265, 1993. 
Biogeosciences Discuss., https://doi.org/10.5194/bg-2018-126

Manuscript under review for journal Biogeosciences

Discussion started: 28 March 2018

(c) Author(s) 2018. CC BY 4.0 License.

Groffman, P. M., Gold, A. J., and Addy, K.: Nitrous oxide production in riparian zones and its importance to national emission inventories, Chemosphere: Global Change Sci., 2, 291-299, 2000.

Parton, W. J., Mosier, A. R., and Schimel, D. S.: Rates and pathways of nitrous oxide production in a shortgrass steppe, Biogeochemistry, 6, 45-48, 1988.

Hartel, P. G., and Alexander, M.: Effect of growth rate on the growth of bacteria in freshly moistened soil, Soil Sci. Soc. Am. J., 50, 308-313, 1987.

Henault, C., Cheneby, D., Heurlier, K., Garrido, F., Perez, S., and Germon, J. C.: Laboratory kinetics of soil denitrification are useful to discriminate soils with potentially high levels of $\mathrm{N}_{2} \mathrm{O}$ emission on the field scale, Agronomie, 21, 713-723, 2001.

Henault, C., Bizouard, F., Laville, P., Gabrielle, B., Nicoullaud, B., Germon, J. C., and Cellier, P.: Predicting in situ soil N 2 O emission using NOE algorithm and soil database, Global Change Biol., 11, 115-127, doi: 10.1111/j.13652486.2004.00879.x, 2005.

Henault, C., Grossel, A., Mary, B., Roussel, M., and Leonard, J.: Nitrous Oxide Emission by Agricultural Soils: A Review of Spatial and Temporal Variability for Mitigation, Pedosphere, 224, 426-433, 2012.

Henault, C. and Germon, J. C.: NEMIS: a predictive model of denitrification on the field scale, Eur. J. Soil Sci., 51, 257-270, 2000 .

He, H., Jansson, P. E., Svensson, M., Meyer, A., Klemedtsson, L., and Kasimir, A.: Factors controlling nitrous oxide emission from a spruce forest ecosystem on drained organic soil, derived using the CoupModel, Ecol. Model., 321, 46$63,2016$.

Hosen, Y., Tsuruta, H., and Minami, K.: Effects of the depth of $\mathrm{NO}$ and $\mathrm{N}_{2} \mathrm{O}$ productions in soil on their emission rates to the atmosphere: analysis by a simulation model, Nutr. Cycl. Agroecosys., 57, 83-98, 2000.

Hu, H. W., Chen, D. L., and He, J. Z.: Microbial regulation of terrestrial nitrous oxide formation: understanding the biological pathways for prediction of emission rates, FEMS Microbiol. Rev., 39, 729-749, doi:10.1093/femsre/fuv021, 2015.

Huang, T., Gao, B., and Hu, X. K.: Ammonia-oxidation as an engine to generate nitrous oxide in an intensively managed calcareous Fluvo-aquic soil, Sc. Rep., 4, 3950, 2014.

Ingwersen, J., Butterbach-Bahl, K., Gasche, R., Richter, O., and Papen, H.: Barometric process separation: new method for quantifying nitrification, denitrification, and nitrous oxide sources in soils, Soil Sci. Soc. Am. J., 63, 117-128, 1999.

Isobe, H., Koba, K., Suwa, Y. C., Ikutani, J. K., Fang, Y. T., Yoh, M., Mo, J. M., Otssuka, S., and Senoo, K.: High abundance of ammonia-oxidizing archaea in acidified subtropical forest soils in southern China after long-term $\mathrm{N}$ deposition, FEMS Microbiol. Rev., 80, 193-203, 2016.

350 IPCC: Decision IPCC/XLVI-2: Chapter outlines of the working group contribution to the IPCC sixth assessment report AR6, IPCC Secretariat, Montreal, Canada, 2017. 
Biogeosciences Discuss., https://doi.org/10.5194/bg-2018-126

Manuscript under review for journal Biogeosciences

Discussion started: 28 March 2018

(c) Author(s) 2018. CC BY 4.0 License.

Khalil, K., Mary, B., and Renault, P.: Nitrous oxide production by nitrification and denitrification in soil aggregates as affected by $\mathrm{O}_{2}$ concentration, Soil Biol. Biochem., 36, 687-699, 2004.

Kim, D. H., Matsuda, O., and Yamamoto, T.: Nitrification, denitrification and nitrate reduction rates in the sediment of Hiroshima Bay, Japan, J. Oceanogr., 53, 317-324, 1997.

Kool, D. M., Dolfing, J., and Wrage, N.: Nitrifier denitrification as a distinct and significant source of nitrous oxide from soil, Soil Biol. Biochem., 43, 174-178, 2011.

Lamarque, J. F., Kiehl, J. T., Brasseur, G. P., Butler, T., Cameron-Smith, P., Collins, W. D., Granier, C., Hauglustaine, D. A., Hess, P. G., Holland, E. A., Horowitz, L. W., Lawrence M. G., Mckenna, D. S., Merilees, P., Prather, M. J., Rasch, P. J., Rotman, D. A., Shindell, D. T., and Thornton, P. E.: Assessing future nitrogen deposition and carbon cycle feedback using a multimodel approach: Analysis of nitrogen deposition, J. Geophys. Res.-Atmos., 110D19, 303.1-303.21. doi: 10.1029/2005JD005825, 2005.

Li, C., Frolking, S., and Frolking, T. A.: A model of nitrous oxide evolution from soil driven by rainfall events: I. model structure and sensitivity, J. Geophys. Res., 97, 9759-9776, 1992.

Li, C. S., Aber, J., Stange, F., Butterbach-Bahl, K., and Papen, H.: A process-based model of $\mathrm{N}_{2} \mathrm{O}$ and NO emissions from forest soils: 1. Model-development, J. Geophys. Res., 105, 4396-4384, 2000.

Litton, C. M., Raich, J. W., and Ryan, M. G.: Carbon Allocation in Forest Ecosystems, Global Change Biol., 1310, 20892109. doi:10.1111/j.1365-2486.2007.01420.x, 2007.

Liu, L. L, and Greaver, T. L.: A review of nitrogen enrichment effects on three biogenic GHGs: the $\mathrm{CO}_{2}$ sink may be largely offset by stimulated $\mathrm{N}_{2} \mathrm{O}$ and $\mathrm{CH}_{4}$ emission, Ecol. Lett., 12, 1103-1117. doi: 10.1111/j.1461-0248.2009.01351.x, 2009.

Liu, X. J., Zhang, Y., Han, W. X., Tang, A. H., Shen, J. L., Cui, Z. L., Vitousek, P. M., Erisman, J. W., Goulding, K. W. T., Christie, P., Fangmeier, A., and Zhang, F. S.: Enhanced nitrogen deposition over China, Nature, 494, 459-464. doi:10.1038/nature11917, 2013.

Lu, X. H., Hong, J., Zhang, X. Y., Liu, J. X., and Jin, J. X.: Estimating 40 years of nitrogen deposition in global biomes using the SCIAMACHY NO 2 column, Int. J. Remote Sens., 37, 20, 4964-4978, 2016.

Monteny, G. J., Bannink, A., and Chadwick, D.: Greenhouse gas abatement strategies for animal husbandry, Agr. Ecosyst. Environ., 112, 163-170, 2006.

Neff, J. C., Holland, E. A., Dentender, F. J., McDoWell, W. H., and Russell, K. M.: The origin, composition and rates of organic nitrogen deposition: A missing piece of the nitrogen cycle? Biogeochemistry, 571, 99-136. doi: 10.1023/A:1015791622742, 2002.

Parton, W. J., Holland, E. A., Del Grosso, S. J., Hartman, M. D., Martin, R. E., Mosier, A. R., Ojima, D. S., and Schimel, D. S.: Generalized model for $\mathrm{NO}_{\mathrm{x}}$ and $\mathrm{N}_{2} \mathrm{O}$ emissions from soils, J. Geophys. Res., 10615, 17403-17419. doi: 10.1029/2001JD900101, 2001. 
Biogeosciences Discuss., https://doi.org/10.5194/bg-2018-126

Manuscript under review for journal Biogeosciences

Discussion started: 28 March 2018

(c) Author(s) 2018. CC BY 4.0 License.

Parton, W. J., Mosier, A. R., Ojima, D. S., Valentine, D. W., Schimel, D. S., Weier, K., and Kulmala, A. E.: Generalized model for $\mathrm{N}_{2}$ and $\mathrm{N}_{2} \mathrm{O}$ production from nitrification and denitrification. Global Biogeochem. Cy., 103, 401-412, doi:10.1029/96GB01455, 1996.

Parton, W. J., Moiser, A. R., and Schimel, D. S.: Rates and pathways of nitrous oxide production in a shortgrass steppe, Biogeochemistry, 6, 45-58, 1988.

Potter, C. S., Riley, R. H., and Klooster, S. A.: Simulation modeling of nitrogen trace gas emissions along an age gradient of tropical forest soils, Ecol. Model., 97, 179-196, 1997.

Potter, C. S., Matson, P. A., Vitousek, P. M., and Davidson, E. A.: Process modeling of controls on nitrogen trace gas emissions from soils worldwide, J. Geophys. Res., 101, 1361-1377, 1996.

Ravishankara, A. R., Daniel, J. S., and Portmann, R.W.: Nitrous oxide $\mathrm{N}_{2} \mathrm{O}$ : the dominant ozone-depleting substance emitted in the 21st century, Science, 326, 123-125, doi:10.1126/science.1176985, 2009.

Ridgwell, A. J., Marshall, S. J., and Gregson, K.: Consumption of atmospheric methane by soils: A process-based model, Global Biogeochem. Cy., 131, 59-70, 1999.

Schmidt, U., Thoni, H., and Kaupenjohann, M.: Using a boundary line approach to analyze $\mathrm{N}_{2} \mathrm{O}$ flux data from agricultural soils, Nutr. Cycl. Agroecosys., 57, 119-129, 2000.

Senapati, N., Chabbi, A., Giostri, F. A., Yeluripati, J. B., and Smith, P.: Modelling nitrous oxide emissions from mowngrass and grain-cropping systems: Testing and sensitivity analysis of DailyDayCent using high-frequency measurements, Sci. Total Environ., 572, 955-977, 2016.

Shan, D. B., and Couiman, G. A.: Kinetics of nitrification and denitrification reactions, Biotechnology and Bioengineering, 20, 43-72, 1978.

Sheldon, A. I., and Barnhart, E. P.: Nitrous oxide emissions research progress Environmental Science, Engineering and Technology, Nova Science Publishers, Hauppauge, NY, 85-120, 2009.

Smith, K. A., Ball, T., Conen, F., Dobbie, K. E., Massheder, J., and Rey, A.: Exchange of greenhouse gases between soil and atmosphere: Interactions of soil physical factors and biological processes, Eur. J. Soil Sci., 54, 779-791. 2003

Starry, O. S., Valett, H. M., and Schreiber, M. E.: Nitrification rates in a headwater stream: influences of seasonal variation in C and N supply, J. N. Am. Benthol. Soc., 24, 753-768, 2005.

410 Tian, D. L., and Niu, S. L.: A global analysis of soil acidification caused by nitrogen addition, Environ. Res. Lett., 10, doi:10.1088/1748-9326/10/2/024019, 2015.

Tian, H. Q., Xu, X., Liu, M., Ren, W., Zhang, C., Chen, G., and Lu, C.: Spatial and temporal patterns of $\mathrm{CH}_{4}$ and $\mathrm{N}_{2} \mathrm{O}$ fluxes in terrestrial ecosystems of North America during 1979-2008: application of a global biogeochemistry model, Biogeosciences, 7, 2673-2694, doi:10.5194/bg-7-2673-2010, 2010.

415 Treseder, K.: Nitrogen additions and microbial biomass: a meta-analysis of ecosystem studies, Ecol. Lett., 11, 1111-1120, 2008.

Van Verseveld, H. W., Meijer, E. M., and Stouthamer, A. H.: Energy conservation and during nitrate respiration in 
Biogeosciences Discuss., https://doi.org/10.5194/bg-2018-126

Manuscript under review for journal Biogeosciences

Discussion started: 28 March 2018

(c) Author(s) 2018. CC BY 4.0 License.

Paracoccus denitrifications, Arch. Microbiol., 112, 17-23, 1977.

Wang, Y. D., Li, Q. K., Wang, H. M., Wen, X. F., Yang, F. T., Ma, Z. Q., Liu. Y. F., and Yu, G. R.: Precipitation frequency controls interannual variation of soil respiration by affecting soil moisture in a subtropical forest plantation, Can. J. Forest Res., 419, 1897-1906, 2011.

Wang, Y. S., Cheng, S. L., Fang, H. J., Yu, G. R., Yang, X. M., Xu, M. J., Dang, X. S., Li, L. S., and Wang, L.: Relationships between ammonia-oxidizing communities, soil methane uptake and nitrous oxide fluxes in a subtropical plantation soil with nitrogen enrichment, Eur. J. Soil Sci., 84-92, 2016.

Webster, E. A., and Hopkins, D. W.: Contributions from different microbial processes to $\mathrm{N}_{2} \mathrm{O}$ emission from soil under different moisture regimes, Biol. Fert. Soils, 22, 331-335, 1996.

Well, R., and Flessa, H.: Isotope fractionation factors of $\mathrm{N}_{2} \mathrm{O}$ diffusion, Rapid Commun. Mass Sp., 22, $2621-2628,2008$.

Well, R., Flessa, H., Lu, X., Ju, X. T., and Volker, R.: Isotopologue ratios of $\mathrm{N}_{2} \mathrm{O}$ emitted from microcosms with $\mathrm{NH}_{4}{ }^{+}$ fertilized arable soils under conditions favoring nitrification, Soil Biol. Biochem., 40, 2416-2426, 2008.

WMO: Scientific Assessment of Ozone Depletion: 2010, Global Ozone Research and Monitoring Project-Report No. 52, World Meteorological Organization, Geneva, Switzerland, 516, 2011.

WMO: Assessment for Decision-Makers: Scientific Assessment of Ozone Depletion: 2014, Global Ozone Research and Monitoring Project-Report No. 56, World Meteorological Organization, Geneva, Switzerland, 88, 2014.

$\mathrm{Xu}, \mathrm{X}$., Tian, H., and Hui, D.: Convergence in the relationship of $\mathrm{CO}_{2}$ and $\mathrm{N}_{2} \mathrm{O}$ exchanges between soil and atmosphere within terrestrial ecosystems, Global Change Biol., 14, 1651-1660, 2008.

Xu, R., and Prentice, C.: Terrestrial nitrogen cycle simulation with a dynamic global vegetation model, Global Change Biol., 14, 1745-1764. doi: 10.1111/j.1365-2486.2008.01625.x, 2008.

Yeluripati, J. B., del Prado, A., Sanz-Cobena, A., Rees, R. M., Li, C. S., Chadvick, D., Tilston, E., Topp, C. F. E., Cardenas, L. M., Ingraham, P., Gilhespy, S., Anthony, S., Vetter, S. H., Misselbrook, T., Salas, W., and Smith, P.: Global Research Alliance Modelling Platform GRAMP: An open web platform for modelling greenhouse gas emissions from agroecosystems, Comput. Electron. Agr., 111, 112-120, 2015.

Zhuang, Q. L., Lu, Y. Y., and Chen, M.: An inventory of global $\mathrm{N}_{2} \mathrm{O}$ emissions from the soils of natural terrestrial ecosystem, Atmos. Environ., 47, 66-75, 2012. 